\title{
APAKAH PEMBIAYAAN BANK SYARIAH DAN TINGKAT PENDIDIKAN BERPENGARUH TERHADAP PERTUMBUHAN EKONOMI PADA ENAM PROVINSI DI PULAU JAWA?
}

\author{
Muhammad Jagat Dermawan \\ Jurusan Ilmu Ekonomi dan Keuangan Islam, UPI Bandung, Email: mjagatd@upi.edu
}

\begin{abstract}
Our research aimed to analyze causality relations between Sharia bank financing and educational level to economic growth. At the same time, Indonesia growth of economic in the last decade is considered high meanwhile, the Sharia bank financing is considered low. And there is a fact that a few provinces which their educational level is considered low, however their economic growth increase high, such as Maluku and Papua, which had the highest economic growth in 2018, followed by Celebes and Java in the second and the third position respectively. We used panel data analysis with the approach of the random effect method in this paper.
\end{abstract}

Keywords: Finance, Educational Level, GDP

\begin{abstract}
ABSTRAK
Penelitian kami dengan tujuan untuk menganalisa hubungan kausalitas antara pembiayaan bank syariah serta tingkat pendidikan terhadap tingkat pertumbuhan ekonomi. Dimana pertumbuhan ekonomi Indonesia pada 10 tahun terakhir ini dinilai cukup tinggi. Sedangkan pertumbuhan pembiayaan perbankan syariah sebagai lembaga keuangan yang dapat membantu pertumbuhan ekonomi dinilai lamban. Juga terdapat fakta beberapa provinsi di Indonesia, dimana tingkat pendidikannya tergolong masih rendah, namun pertumbuhan ekonominya mengalami peningkatan yang terbilang tinggi, seperti halnya Maluku dan Papua yang mengalami pertumbuhan ekonomi tertinggi ditahun 2018, disusul Sulawesi diurutan kedua dan pulau Jawa diurutan ke tiga. Metode yang kami gunakan pada penelitian ini adalah analisis data penel menggunakan pendekatan random effect method.
\end{abstract}

Kata Kunci: pembiayaan, tingkat pendidikan, pdb

\section{PENDAHULUAN}

Produk Domestik Bruto (PDB) yang mewakili pertumbuhan ekonomi Indonesia pada 10 tahun terakhir ini cukup stabil bahkan dapat dikategorikan tinggi jika perbandingannya 


\section{Doi : $\mathbf{1 0 . 3 7 0 5 8 / j e s . v 5 i 2 . 1 9 4 9}$}

itu dengan negara berkembang yang lainnya. Dengan menggunakan data yang dipublikasikan oleh Badan Pusat Statistik (BPS) tingkat pertumbuhan ekonomi Indonesia berada pada kisaran 5\% dalam 10 tahun terakhir.

Disisi lain pertumbuhan bank syariah (sektor keuangan) yang menjadi satu faktor diantara yang lainnya, dianggap mampu mendukung tumbuh kembang ekonomi memperlihatkan masih belum menunjukkan peran yang diharapkan. Menurut laporan, pada kuartal III-2018 dan sebelumnya, kinerja bank umum syariah (BUS) dari sisi pembiayaannya mengalami pelambatan. Apabila disempitkan berdasarkan kategori usaha, Bank Umum Kelompok Usaha (BUKU) I yang mengalami penurunan paling buruk. BUS BUKU I pada Juli 2018 mencata pada sektor industri mengalami penyusutan pembiayaan yang cukup drastis menjadi negatif 10,54\%. Sementara itu, pada setahun sebelumnya, pembiayaan pada BUKU I syariah mengalami pertumbuhan sebesar 6,33\%. Kemudian baik BUKU II maupun BUKU III syariah mengalami penyusutan pertumbuhan pembiayaan menjadi $3,35 \%$ dan $8,51 \%$. Jika dibandingkan dengan tahun sebelumnya yang mampu naik hingga 8,17\% dan 8,51\% pada Juli 2017 (“Agustus, pertumbuhan kredit perbankan melambat," n.d.).

Di bawah ini disajikan tabel pertumbuhan ekonomi Indonesia dan pembiayaan bank syariah dari tahun 2009-2018.

TABEL 1

DATA PERTUMBUHAN EKONOMI INDONESIA DAN PEMBIAYAAN BANK SYARIAH 2009-2018

\begin{tabular}{|c|c|c|}
\hline Tahun & PDB & PEMBIAYAAN BANK SYARIAH \\
\hline 2009 & 1303666.38 & 1354873.656 \\
\hline 2010 & 1395689.34 & 1718442.258 \\
\hline 2011 & 1472742.2 & 2268258.074 \\
\hline 2012 & 1561416.15 & 3016344.149 \\
\hline 2013 & 1606367.61 & 3975781.385 \\
\hline 2014 & 1682633.63 & 4423009.167 \\
\hline 2015 & 1770952.22 & 5130200.519 \\
\hline 2016 & 1857257.63 & 6026102.005 \\
\hline 2017 & 1951182.17 & 7076138.437 \\
\hline 2018 & 2046638.88 & 8370792.826 \\
\hline
\end{tabular}

Sumber : BPS dan SPS data diolah kembali 
Bahkan bila melihat data Statistik Perbankan Syariah (SPS) milik Otoritas Jasa Keuangan (OJK), keadaan pembiayaan bermasalah (non-performing financing/NPF) konvensional lebih rendah daripada syariah. Pada akhir Maret, tingkat NPF ada pada 3,44\%, dan disisi lain, kredit bermasalah perbankan konvensional (NPL) ada pada 2,5\%. Jika melihat periode sebelumnya, tingkat pembiayaan bermasalah perbankan syariah lebih besar lagi. Contohnya pada akhir 2017 yang mencapai 4,76\% ataupun 2016 yang mencapai 4,42\% (Hastuti, n.d.). Dari data diatas sangat menarik untuk diteliti karena pembiayaan perbankan Islam di Indoensia mengalami pertumbuhan yang tidak menggembirakan. Sementara pertumbuhan ekonomi dalam sepuluh tahun terakhir ini mengalami peningkatan.

Adapun pembiayaan perbankan syariah yang telah disalurkan di enam provinsi yang ada di pulau Jawa selama periode 2009-2018, seperti terlihat pada tabel di bawah ini:

TABEL 2

TOTAL PEMBIAYAAN BANK SYARIAH

PADA ENAM PROVINSI DI PULAU JAWA 2009-2018

\begin{tabular}{|r|c|c|}
\hline Tahun & Total/tahun & Pertumbuhan \\
\hline 2009 & 1171172 & \\
\hline 2010 & 1475844 & $4.33 \%$ \\
\hline 2011 & 1970371 & $5.67 \%$ \\
\hline 2012 & 2622773 & $5.50 \%$ \\
\hline 2013 & 3414213 & $5 \%$ \\
\hline 2014 & 3882912 & $2.33 \%$ \\
\hline 2015 & 4470992 & $2.50 \%$ \\
\hline 2016 & 5144778 & $2.50 \%$ \\
\hline 2017 & 5997963 & $2.83 \%$ \\
\hline 2018 & 7086335 & $3 \%$ \\
\hline
\end{tabular}

Sumber : OJK SPS data diolah Kembali

Dari data tersebut menunjukkan total pembiayaan perbankan syariah yang dikeluarkan di enam provinsi yang ada di pulau Jawa pertumbuhannya berpluktuasi. Pertumbuhan pada tahun 2011 adalah yang tertinggi dengan kisaran $5.67 \%$ dan pertumbuhan pada tahun 2015 dan 2016 adalah yang terendah dengan kisaran hanya $2.50 \%$.

Berikut tabel pertumbuhan ekonomi di pulau Jawa dalam periode peneletian, yang diambil dari tahun 2009 hingga tahun 2018: 
TABEL 3

PERTUMBUHAN EKONOMI ATAS DASAR HARGA KONSTAN PADA ENAM PROVINSI DI PULAU JAWA

Miliar Rupiah

\begin{tabular}{|l|l|r|l|l|l|r|}
\hline TAHUN & DKI & JABAR & BANTEN & JATENG & DIY & JATIM \\
\hline 2009 & 1002808,73 & 847749,46 & 252384,72 & 590181,11 & 61308,07 & 926895,91 \\
\hline 2010 & 1075183,48 & 906685,76 & 271465,28 & 623224,62 & 64678,97 & 990648,84 \\
\hline 2011 & 1147558,23 & 965622,06 & 290545,84 & 656268,13 & 68049,87 & 1054401,77 \\
\hline 2012 & 1222527,92 & 1028409,74 & 310385,59 & 691343,12 & 71702,45 & 1124464,64 \\
\hline 2013 & 1296694,57 & 1093543,55 & 331099,11 & 726655,12 & 75627,45 & 1192789,80 \\
\hline 2014 & 1373389,13 & 1149216,06 & 349351,23 & 764959,15 & 79536,08 & 1262684,50 \\
\hline 2015 & 1454563,85 & 1207232,34 & 368377,20 & 806765,09 & 83474,45 & 1331376,10 \\
\hline 2016 & 1540078,20 & 1275527,64 & 387824,35 & 849313,20 & 87688,20 & 1405561,04 \\
\hline 2017 & 1635855,75 & 1342953,38 & 409959,69 & 894050,47 & 92300,66 & 1482147,59 \\
\hline 2018 & 1736788,05 & 1418695,95 & 423775,36 & 911613,96 & 94023,30 & 1521720,93 \\
\hline
\end{tabular}

\section{Sumber BPS data diolah kembali}

Dari data di atas menunjukkan bahwa pertumbuhan ekonomi pada enam provinsi di pulau Jawa setiap tahunnya selalu meningkat. Namun hal yang menarik adalah provinsi DKI Jakarta yang menunjukkan pertumbuhan ekonomi yang selalu tertinggi diantara enam provinsi tersebut, padahal provinsi DKI Jakarta berdasarkan data SPS pembiayaan yang dikucurkan perbankan syariah relative sedikit dibanding dengan provinsi lainnya seperti Jawa Barat, Banten, Jawa Tengah, DIY dan Jawa Timur.

Faktor lain yang dapat mempengaruhi pertumbuhan ekonomi adalah kualitas sumber daya manusia. Pendidikan merupakan salah satu cara yang dapat meningkatkan kualitas SDM tersebut. Untuk mengetahui seberapa banyak penduduk yang memanfaatkan fasilitas pendidikan salah satunya dapat dilihat dari persentase penduduk menurut partisipasi sekolah dengan melihat Angka Partisipasi Murni (APM) wilayah tersebut. Angka partisipasi murni (APM) adalah perbandingan antara siswa usia sekolah tertentu pada jenjang pendidikan dengan penduduk usia yang sesuai dan dinyatakan dalam persentase. Kriterianya adalah semakin tinggi APM berarti semakin banyak anak usia sekolah yang bersekolah sesuai usia resmi di jenjang pendidikan tertentu. (“APK-APM,” n.d.).

Adapun angka partisipasi murni (APM) pada enam provinsi di pulau Jawa dalam kurun waktu 2009 sampai dengan 2018 seperti terlihat pada tabel dibawah ini: 
TABEL 4

ANGKA PARTISIPASI MURNI (APM) SM, SMK, MA, DAN PAKET C PADA ENAM PROVINSI DI PULAU JAWA

\begin{tabular}{|l|l|l|l|l|l|l|}
\hline TAHUN & DKI & JABAR & BANTEN & JATENG & DIY & JATIM \\
\hline 2009 & 50.43 & 38.59 & 38.77 & 44.53 & 58.69 & 48.26 \\
\hline 2010 & 50.57 & 38.84 & 39.61 & 45 & 59.35 & 48.6 \\
\hline 2011 & 49.91 & 42.45 & 46.24 & 47.17 & 59.25 & 49.29 \\
\hline 2012 & 54.25 & 51.24 & 53 & 51.11 & 63.54 & 52.36 \\
\hline 2013 & 55.4 & 52.25 & 53.28 & 51.81 & 64.86 & 53.3 \\
\hline 2014 & 58.79 & 56.48 & 56.87 & 58.11 & 68.46 & 60 \\
\hline 2015 & 59.04 & 56.73 & 57.04 & 58.27 & 68.6 & 60.31 \\
\hline 2016 & 59.3 & 56.92 & 57.21 & 58.49 & 68.96 & 60.76 \\
\hline 2017 & 59.54 & 57.22 & 57.88 & 59.2 & 69.66 & 61.49 \\
\hline 2018 & 60.01 & 57.33 & 58.72 & 59.31 & 70.22 & 61.51 \\
\hline
\end{tabular}

\section{Sumber BPS data diolah kembali}

Data di atas adalah data dengan jenjang pendidikan Sekolah Menengah (SM), Sekolah Menengah Kejuruan (SMK), Madrasah Aliyah (MA) dan paket C (jenjang pendidikan setingkat Sekolah Menengah. Dimana angka parisipasi murni (APM) pada enam provinsi di pulau Jawa menunjukkan diatas 50. Meskipun pada tahun 2009 dan 2010 provinsi Jawa Barat, Banten dan Jawa Tengah berada dibawah 50.

\section{LITERATUR REVIEW DAN HIPOTESIS}

Sejak berdirinya dan berkembangnya industri perbankan sebagai lembaga pemberi modal tidak sedikit peneliti yang meneliti tentang pengaruh sektor keuangan dapat menjadi pendorong pertumbuhan ekonomi. Menurut Ghali, Copelman, Graff, Fritzer, Allen, Lee, dan Valey, bahwa dari hasil studinya mereka mendukung hipotesis bahwa sektor keuangan menjadi katalistaor dalam pertumbuhan ekonomi (supply leading hypothesis) (Inggrid, 2006). Sementara studi yang dilakukan Patrick di Negeria, dimana dari hasil penelitiannya menunjukkan bahwa supply leading hypothesis memiliki pengaruh yang lemah pada pertumbuhan ekonomi di Nigeria. Hal ini wajar karena perkembangan sektor keuangan di Nigeria belum begitu berkembang seperti di negara-negara maju. Sehingga pertumbuhan ekonomi di Nigeria lebih banyak didorong oleh sektor riil. Namun dalam kesimpulannya menyatakan bahwa perkembangan sektor 


\section{Doi : $\mathbf{1 0 . 3 7 0 5 8 / j e s . v 5 i 2 . 1 9 4 9}$}

keuangan dapat mempengaruhi pertumbuhan ekonomi dengan memperbanyak kapasitas bank untuk dapat memperbanyak kredit kepada sektor riil (Olufemi Adeyeye, 2015).

Menurut Megginson, teori intermediasi (Intermediation Theory) membahas tentang eksistensi lembaga perantara keuangan, terutama bank umum atau bank komersial karena bank memiliki keunggulan kompetitif yang jelas atas pasar modal untuk semua pendanaan-pendanaan perusahaan. Perantara keuangan dan pasar keuangan adalah dua lembaga penting, yang berkontribusi terhadap alokasi sumber daya yang optimal dalam suatu perekonomian (Jaelani, 2015). Teori intermediasi keuangan sangat terkait makro ekonomi, menurut Andries bahwa teori intermediasi keuangan modern membahas bagaimana intermediasi keuangan mempengaruhi ekonomi secara keseluruhan (Jaelani, 2015).

Sementara berdasarkan salah satu studi yang terkenal yang dilakukan oleh Denison yang menganalisis faktor yang mengakibatkan perkembangan di Negara maju di antara tahun 1950-1962. Kesimpulan kajiannya tersebut adalah, pertambahan barang-barang modal hanya mewujudkan 25 persen dari pertumbuhan ekonomi di Amerika Serikat, 18 persen dari pertumbuhan ekonomi di Eropa Barat dan 21 persen dari pertumbuhan ekonomi yang terjadi di Inggris, menunjukkan bahwa teknologi dan perkembangan keterampilan yang menjadi faktor utama yang mewujudkan pertumbuhan ekonomi (Sukirno, 2006). Sedangkan menurut Arsyad bahwa faktorfaktor yang dapat mempengaruhi pertumbuhan ekonomi diantaranya adalah 1. Akumulasi modal, termasuk semua investasi baru yang berwujud tanah, peralatan fisik (mesin-mesin), dan sumber daya manusia (human resources) 2. Pertumbuhan penduduk, 3. Kemajuan teknologi, 4. Sumber daya institusi (sistem kelembagaan) (Arsyad, 2016).

Sedangkan teori modal manusia menjelaskan proses dimana pendidikan memiliki pengaruh positif pada pertumbuhan ekonomi. Teori ini telah mendominasi literatur pembangunan ekonomi dan pendidikan dari pasca perang dunia kedua sampai pada tahun 70-an. Para pelopornya antara lain adalah pemenang hadian Nobel ilmu ekonomi Gary Becker dari Universitas Chicago, Amerika Serikat, Edward Denison dan Theodore Schultz, yang juga pemenang hadiah nobel ekonomi atas penelitiannya tentang masalah ini. Argumensi yang disampaikan oleh pendukung teori ini adalah 


\section{Doi : $\mathbf{1 0 . 3 7 0 5 8 / j e s . v 5 i 2 . 1 9 4 9}$}

manusia yang memiliki tingkat pendidikan lebih tinggi, yang diukur juga dengan lamanya waktu sekolah, akan memiliki pekerjaan dan upah yang lebih baik dibandingkan dengan yang pendidikannya lebih rendah. Apabila upah mencerminkan produktivitas, maka semakin banyak orang yang memiliki pendidikan tinggi, maka akan semakin tinggi produktivitas, sehingga hasilnya ekonomi nasional akan bertumbuh lebih tinggi (Nugroho, 2014).

Dari uraian di atas jelaslah bahwa jumlah penduduk, serta tenaga kerja yang terampil dan terdidik sangat berpengaruh terhadap pertumbuhan ekonomi suatu negara. Namun ternyata berbeda kenyatannya dengan beberapa provinsi di Indonesia, dimana terdapat beberapa provinsi yang tingkat pendidikan dan keterampilannya tergolong relative rendah bila dibandingkan dengan provinsi lainnya yang ada di Indonesia, namun pertumbuhan ekonominya tertinggi di Indonesia seperti pertumbuhan ekonomi di wilayah Maluku dan Papua mencapai 9,7 persen hingga akhir tahun 2018. Angka itu terpaut jauh dari pertumbuhan ekonomi wilayah Jawa yang berkisar 5,7 persen. Pertumbuhan ekonomi tertinggi kedua disumbang dari Sulawesi di 6,8 persen. Disusul oleh Jawa, Sumatra, Kalimantan, serta Bali dan Nusa Tenggara ("Pertumbuhan Ekonomi Maluku dan Papua Diproyeksi Lampaui Jawa,” n.d.). Disinilah hal yang sangat menarik untuk diteliti mengapa pertumbuhan ekonomi dipulau jawa dalam beberapa tahun terakhir ini teringgal oleh wilayah Maluku, Papua dan Sulawesi padahal bila dilihat dari tingkat pendidikannya wilayah pulau Jawa lebih tinggi dibandingkan dengan Maluku, Papua dan Sulawesi.

\section{Pertumbuhan Ekonomi}

Suatu perekonomian dikatakan mengalami pertumuhan ekonomi jika jumlah produksi barang dan jasanya meningkat. Pertumbuhan atau pemerataan? Terlepas dari mana yang lebih penting, yang pasti pertumbuhan ekonomi sangat penting dan dibutuhkan. Sebab, tanpa pertumbuhan tidak akan terjadi peningkatan kesejahteraan, kesempatan kerja, produktifitas dan distribusi pendapatan. Pertumbuhan ekonomi juga penting untuk mempersiapkan perekonomian menjalani tahapan kemajuan selanjutnya (Rahardja \& Manurung, 2014). Pertumbuhan ekonomi biasa diartikan sebagai upaya mencapai tingkat pertumbuhan pendapatan perkapita (income per capita) yang 
Doi : $\mathbf{1 0 . 3 7 0 5 8 / j e s . v 5 i 2 . 1 9 4 9}$

berkelanjutan agar negara dapat memperbanyak output yang lebih cepat dibandingkan laju pertumbuhan penduduk (Todaro \& Smith, 2006).

\section{Pembiayaan Perbankan Syariah}

Perbankan Islam sebagai lembaga keuangan, keberadaannya sangat diperlukan dalam rangka menopang permodalan bagi para pelaku usaha. Dengan beragam jenis pembiayannya, perbankan Islam diharapkan bisa menjadi solusi bagi masyarakat yang memerlukan pembiayaan dengan tidak memakai konsep bunga, yang dipandang sebagai riba yang mesti dijauihi. Meskipun menurut Ayub Industri perbankan dan keuangan Islam sekarang ini menghadapi beberapa tantangan. Tantangan terbesar adalah mengembangkan produk investasi dan pembiayaan yang tidak hanya sesuai dengan prinsip ekonomi syariah, tapi juga memenuhi kebutuhan perdagangan, bisnis, dan industri yang terus berkembang secara berubah, baik dalam sektor swasta maupun sektor publik. Hanya dengan cara inilah mereka dapat memenuhi tantangan untuk membangun keyakinan dan meningkatkan integritas institusi finansial Islam (Ayub, 2013).

Pembiayaan merupakan salah satu tugas pokok bank, yaitu pemberian fasilitas penyediaan dana untuk memenuhi kebutuhan pihak-pihak yang merupakan defisit unit. Menurut sifat penggunaanya, pembiayaan dapat dibagi menjadi dua hal berikut.

1. Pembiayaan produktif, yaitu pembiayaan yang ditujukan untuk memenuhi kebutuhan produksi dalam arti luas, yaitu untuk peningkatan usaha, baik usaha produksi, perdagangan, maupun investasi.

2. Pembiayaan konsumtif, yaitu pembiayaan yang digunakan untuk memenuhi kebutuhan konsumsi, yang akan habis digunakan untuk memenuhi kebutuhan.

Menurut keperluannya, pembiayaan produktif dapat dibagi menjadi dua hal berikut.

1. Pembiayaan modal kerja, yaitu pembiayaan untuk memenuhi kebutuhan: (a) peningkatan produksi, baik secara kuantitatif, yaitu jumlah hasil produksi, maupun secara kualitatif, yaitu peningkatan kualitas atau mutu hasil produksi; dan (b) untuk keperluan perdagangan atau peningkatan utility of place dari suatu barang. 


\section{p-ISSN 2548-5032 e-ISSN 2714-769X}

Doi : $10.37058 /$ jes.v5i2.1949

2. Pembiayaan investasi, yaitu untuk memenuhi kebutuhan barang-barang modal (capital goods) serta fasilitas-fasilitas yang erat kaitannya dengan itu (Antonio, 2001).

\section{Hubungan antara Pembiayaan Perbankan Syariah dan Pertumbuhan Ekonomi}

Menurut Kiryanto Pembangunan ekonomi di suatu negara sangat tergantung pada perkembangan dinamis dan kontribusi nyata dari sektor perbankan. Ketika sektor perbankan terpuruk perekonomian nasional juga ikut terpuruk. Demikian pula sebaliknya, ketika perekonomian mengalami stagnasi sektor perbankan juga terkena imbasnya dimana fungsi intermediasi tidak berjalan normal (Baroroh, 2012).

Menurut Ali Rama, bahwa perkembangan sektor keuangan berpengaruh terhadap pertumbuhan ekonomi, begitu pula sebaliknya. Jika sektor keuangan mengalami pertumbuhan yang baik maka akan semakin banyak sumber pembiayaan yang dapat dialokasikan ke sektor-sektor ekonomi produktif (Rama, 2013).

Arah keterkaitan antara sektor keuangan dengan pertumbuhan ekonomi dapat dijelaskan dalam dua hipotesis, yaitu supply-leading dan demand-following, seperti yang telah dikemukakan oleh Patrick, Hipotesis supply-leading mengedepankan arah hubungan dari perkembangan sektor keuangan terhadap pertumbuhan ekonomi, yang berarti bahwa pembangunan institusi dan pasar keuangan akan meningkatkan penawaran jasa keuangan yang akan mengarah pada pertumbuhan ekonomi riil (Maski, 2010).

\section{Tingkat Pendidikan}

Gagasan investasi pada modal manusia adalah betul-betul baru. Dalam proses pertumbuhan ekonomi, lazimnya orang lebih menekankan arti penting akumulasi modal fisik. Sekarang makin disadari bahwa pertumbuhan persediaan modal nyata sampai batas-batas tertentu tergantung pada pembentukan modal manusia yaitu "proses peningkatan pengetahuan, keterampilan dan kemampuan seluruh rakyat suatu negara" (Jhingan, 2016).

Menurut F.H.Harbison bahwa pengertian pembentukan modal manusia adalah "proses memperoleh dan meningkatkan jumlah orang yang mempunyai keahlian, 
pendidikan dan pengalaman yang menentukan bagi pembangunan ekonomi dan politik suatu negara. Pembentukan modal manusia karenanya dikaitkan dengan investasi pada manusia dan pengembangannya sebagai suatu sumber yang kreatif dan produktif. Menurut Schultz, ada lima cara pengembangan sumber daya manusia:'(1) fasilitas dan layanan kesehatan, pada umumnya diartikan mencakup semua pengeluaran yang mempengaruhi harapan hidup, kekuatan dan stamina, tenaga serta vitalitas rakyat; (2) latihan jabatan, termasuk magang model lama yang diorganisasikan oleh perusahaan; (3) pendidikan yang diorganisasikan secara formal pada tingkat dasar, menengah dan tinggi; (4) program studi bagi orang dewasa yang tidak diorganisasikan oleh perusahaan, termasuk program ekstension khususnya pada pertanian; (5) migrasi perorangan dan keluarga untuk menyesuaikan diri dengan kesempatan kerja yang selalu berubah (Jhingan, 2016).

Faktor Sumber Daya Manusia (SDM). Sama halnya dengan proses pembangunan, pertumbuhan ekonomi juga dipengaruhi oleh SDM. Sumber daya manusia merupakan faktor penting dalam proses pembangunan, cepat lambatnya proses pembangunan tergantung kepada sejauh mana sumber daya manusianya selaku subjek pembangunan memiliki kompetensi yang memadai untuk melaksanakan proses pembangunan dengan membangun infrastruktur di daerah-daerah (Putra, 2018).

\section{Hubungan Antara Pendidikan dan Pertumbuhan Ekonomi}

Tenaga kerja adalah salah satu faktor yang mempengaruhi pendapatan nasional. Dan selama ini kita hanya memperhatikan segi kuntitasnya saja, kita beranggapan, bahwa kalau jumlah tenaga kerja meningkat, maka jumlah produktifitasnya juga meningkat. Pernyataan tersebut tidak seluruhnya benar, karena walupun jumlah tenaga kerja itu tidak berubah, tetapi bila kualitas dari tenaga kerja tersebut lebih baik atau meningkat, maka tingkat produksi juga akan mengalami peningkatan. Sedangkan kemampuan untuk bekerja seseorang dipengaruhi oleh keadaan kesehatan dan kecakapannya, keterampilan dan keahliannya. Selanjutnya tingkat kesehatan dipengaruhi oleh keadaan gizi dan lingkungannya, sedangkan kecakapan, keterampilan, dan keahlian dipengaruhi oleh tingkat pendidikan baik formal maupun informal (Putra, 2018). Bahkan dari pengalaman negara-negara maju terbukti bahwa faktor 


\section{Doi : $\mathbf{1 0 . 3 7 0 5 8 / j e s . v 5 i 2 . 1 9 4 9}$}

yang paling berpengaruh terhadap kemajuan ekonomi adalah kualitas sumber daya manusia (Rahardja \& Manurung, 2014).

\section{Penelitian Terdahulu}

Adapun penelitian terdahulu diambil dari jurnal ilmiah, karena jurnal sebagai sumber yang sangat penting dalam memberikan informasi terkini. Artikel di dalam jurnal akademik secara umum sudah direview oleh para ahlinya yang menandakan artikel tersebut sudah diteliti kembali oleh ahlinya sebelum diterima untuk dipublikasikan (Sekaran \& Bougie, 2016). Adapun sumber jurnal dalam penelitian ini adalah:

1. Penelitian yang dilakukan oleh: Salahuddin El Ayubi, Lukytawati Anggraeni, Almira Dyah Mahiswary. Dengan judul, Pengaruh Bank Syariah terhadap Pertumbuhan Ekonomi Indonesia. Ada hasil estimasi VECM terdapat hubungan pada jangka panjang. Salah satu Variabel yang signifikan berpengaruh terhadap GDP adalah total pembiayaan perbankan syariah. Variabel total pembiayaan perbankan syariah pada lag pertama memiliki hubungan positif terhadap GDP riil dalam jangka panjang, dan signifikan secara statistik pada taraf nyata 1 persen yaitu sebesar 3.362112. Artinya, pada saat terjadi peningkatan penyaluran pembiayaan syariah 1persen pada lag pertama, akan terjadi peningkatan terhadap GDP riil sebesar 3.362112 persen. Alasannya adalah pada saat terjadi peningkatan total pembiayaan yang disalurkan, akan berdampak pada peningkatan modal pada usaha-usaha kemudian hal tersebut menyebabkan peningkatan pada perekonomian sektor riil. Peningkatan pada perekonomian sektor riil berarti terjadi peningkatan aktivitas ekonomi, yang mana akan meningkatkan pertumbuhan ekonomi (El Ayubi, Anggraeni, \& Mahiswary, 2017).

2. Nugroho Dengan judul peneletian, Pengaruh Pendidikan Terhadap Pertumbuhan Ekonomi. Data pendidikan yang di proxy dengan Angka Melek Huruf (AMH), dan ertumbuhan ekonomi diproxy dengan Produk Domestik Bruto (PDB). Hasil analisis uji asumsi klasik dan koefisien determinasi (R2) dengan meng-gunakan program SPSS menunjukkan bahwa koefisien determinasi adalah 0,926 yang berarti 92,6 persen naik turunnya PDB Indonesia bisa dijelaskan oleh Angka Melek Huruf. Sedangkan 6,4 persen oleh faktor-faktor lain seperti variabel lain dan bahwa AMH 


\section{Doi : $\mathbf{1 0 . 3 7 0 5 8 / j e s . v 5 i 2 . 1 9 4 9}$}

berpengaruh secara signifikan terhadap PDB Indonesia pada tingkat signifikansi 5 persen. Sedangkan koefsien regresi yang sudah distandarisasi menunjukkan angka 0,962 yang berarti setiap kenaikan 1 poin AMH akan menaikkan PDB Indonesia sebesar 0,962 milyar rupiah (Nugroho, 2014).

3. Ali Rama. Dengan judul penelitian Perbankan Syariah dan Pertumbuhan Ekonomi Indonesia. Dimana penelitiannya menguji hubungan antara perbankan syariah, pasar modal, perdagangan, dan inflasi pengaruhnya terhadap pertumbuhan ekonomi. Hasil penelitiannya menunjukkan bahwa terdapat hubungan kesimbangan jangka panjang antara bank syariah, pasar modal, perdagangan dan inflasi terhadap pertumbuhan ekonomi. Berdasarkan uji kausalitas Granger menunjukkan bahwa terdapat hubungan dua arah antara pertumbuhan ekonomi dengan bank syariah di Indonesia (Rama, 2013).

Dari berbagai teori dan hasil penelitian di atas maka dapat dibuat model hubungan variabel penelitian sebagai berikut:

Gambar 1

Paradigma Penelitian

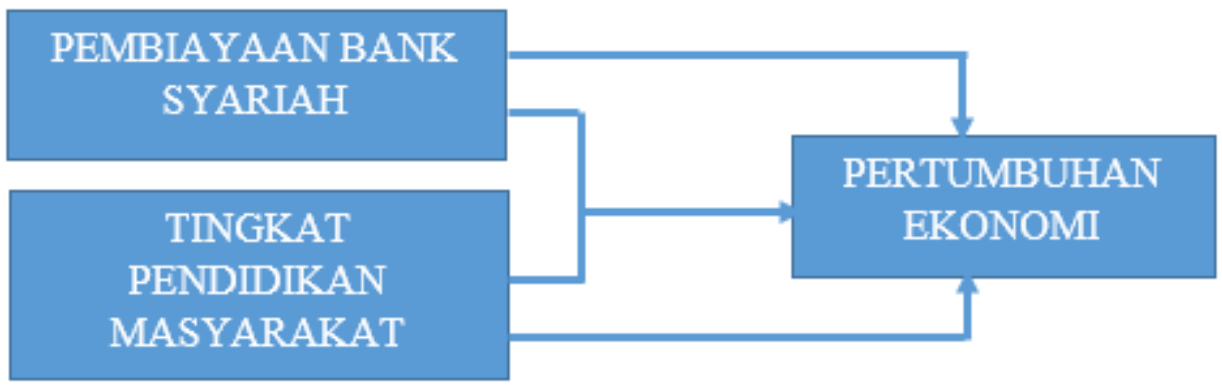

\section{Hipotesis Penelitian:}

H1 : Terdapat pengaruh yang signifikan antara pembiayaan perbankan syariah terhadap pertumbuhan ekonomi pada enam provinsi di Pulau Jawa.

H2 : Terdapat pengaruh yang signifikan antara tingkat pendidikan terhadap pertumbuhan ekonomi pada enam provinsi di Pulau Jawa

H3 : Secara simultan terdapat pengaruh antara variable pembiayaan bank syariah dan tingkat pendidikan terhadap pertumbuhan ekonomi, pada enam provinsi di Pulau Jawa 
Doi : $10.37058 /$ jes.v5i2.1949

\section{METODE}

Penelitian ini menggunakan data panel. Yaitu, gabungan antara data time series (runtut waktu) dan data cross section. Dalam mencari hubungan ketiga variabel penelitian digunakan analisis regresi berganda dengan terlebih dahulu melakukan Uji Chow, Uji Housman dan Uji Lagrange Multiplier, sehingga menghasilkan model regresi data panel yang tepat untuk dipergunakan dalam melakukan uji-uji selanjutnya.

Uji statistik yang dilakukan dalam mencari hubungan antara varibel independen dan dependen adalah dengan melakukan uji signifikansi. Dimana uji-t dilakukan dalam rangka mengetahui hubungan secara parsial, dan uji-f dilakukan untuk mengetahui pengaruh secara simultan kedua variabel independen terhadap variabel dependen. Dan langkah selanjutnya adalah uji Koefisien determinasi $\left(\mathrm{R}^{2}\right)$.

Uji $\mathrm{R}^{2}$ atau uji determinasi dilakukan dalam rangka menjelaskan seberapa besar variasi dari variabel terikat (dependen) dapat diterangkan oleh variabel bebas (independen). Jika koefisien determinasi sama dengan nol $\left(\mathrm{R}^{2}=0\right)$ maka variasi dari variabel terikat tidak dapat diterangkan sama sekali oleh variabel bebas, dan jika $\mathrm{R}^{2}$ $=1$ maka variabel terikat secara keseluruhan dapat diterangkan oleh variabel bebas, dengan kata lain jika $\mathrm{R}^{2}=1$ maka semua titik pengamatan berada tepat pada garis regresi. Setelah tahapan di atas langkah selanjutnya adalah melakukan:

1. Uji t atau pengujian secara parsial

Uji $\mathrm{t}$ digunakan untuk menguji keberartian koefisien arah regresi dari pengaruh variable bebas (independen) terhadap variable terikat (dependen). Dengan menentukan tingkat signifikan $(\alpha)$ yaitu sebesar 5\% berdasarkan nilai probabilitas. Dengan kriteria keputusan sebagai berikut:

a. Jika nilai probabilitas > 0,05 maka H1 diterima, dan Ho ditolak, yang artinya variabel bebas (independent) mempengaruhi variabel terikat (dependent) secara signifikan

b. Jika nilai probabilitas < 0,05 maka H1 ditolak, dan Ho diterima, yang artinya variabel bebas (independent) tidak mempengaruhi variabel terikat (dependent) secara signifikan.

2. Uji F atau pengujian secara simultan 
Uji f dilakukan dalam rangka menguji keberartian koefisien arah regresi dari pengaruh variable-variabel bebas (independen) terhadap variable terikat (dependen) secara simultan (bersamaan). Dengan menentukan tingkat signifikan $(\alpha)$ yaitu sebesar $5 \%$ berdasarkan nilai probabilitas. Dengan kriteria keputusan sebagai berikut:

a. Jika nilai probabilitas > 0,05 maka H1 diterima, dan Ho ditolak, yang artinya variabel bebas (independent) secara serentak atau bersama-sama mempengaruhi variabel terikat (dependent) secara signifikan

b. Jika nilai probabilitas < 0,05 maka H1 ditolak, dan Ho diterima, yang artinya variabel bebas (independent) secara serentak atau bersama-sama tidak mempengaruhi variabel terikat (dependent) secara signifikan.

\section{HASIL DAN PEMBAHASAN}

\section{Pengujian Statistik}

Dari hasil uji Chow dan uji Housman yang telah dilakukan untuk pemilihan model, model yang terbaik dalam penelitian ini adalah Random Effect Model (REM). Maka model REM akan dipergunakan dalam uji-uji selanjutnya.

Tabel 5.

Hasil Uji Hausman

\begin{tabular}{lccc}
\hline \hline & Chi-Sq. & & \\
Test Summary & Statistic & Chi-Sq. d.f. & Prob. \\
\hline \hline Cross-section random & 1.049581 & 2 & 0.5917 \\
\hline \hline
\end{tabular}

Cross-section random effects test comparisons:

\begin{tabular}{ccccc} 
Variable & Fixed & Random & Var(Diff.) & Prob. \\
\hline \hline X1PMBY & 0.167449 & 0.172374 & 0.000046 & 0.4662 \\
X2PDDKN & 11153.262690 & 10803.954359 & 182785.212403 & 0.4139 \\
\hline \hline
\end{tabular}

\section{Pengujian Uji Asumsi Klasik}

\section{Uji Normalitas dengan Metode Random Effect.}

Menurut Gujarati, bahwa uji asumsi normalitas secara eksplisit biasa dilakukan untuk menganalisis sampel yang terbatas atau sedikit (Gujarati, 2013). Dibawah ini 


\section{Doi : $\mathbf{1 0 . 3 7 0 5 8 / j e s . v 5 i 2 . 1 9 4 9}$}

disajikan hasil uji normalitas dari data pertumbuhan ekonomi, kesempatan kerja, kesejahteraan masyarakat serta pertumbuhan perbankan syariah:

\section{Tabel 6.}

\section{Hasil Uji Normalitas}

\begin{tabular}{|c|c|}
\hline \multicolumn{2}{|c|}{$\begin{array}{l}\text { Series: Standardized Residuals } \\
\text { Sample } 20092018 \\
\text { O bservations } 60\end{array}$} \\
\hline Mean & $5.37 e-10$ \\
\hline Median & 79781.83 \\
\hline Maximum & 955449.2 \\
\hline Minimum & -854263.4 \\
\hline Std. Dev. & 483562.2 \\
\hline Skewness & -0.251453 \\
\hline Kurtosis & 2.098632 \\
\hline Jarque-B era & 2.663444 \\
\hline P robability & 0.264022 \\
\hline
\end{tabular}

Hasil diatas menunjukkan bahwa variabel-variabel penelitian menunjukan berdistribusi normal. Karena p-value Jarque Bera lebih besar dari taraf signifikansi $(=5 \%)$ maka distribusi residual persamaan regresi berdistribusi normal, atau jika nilai probabilitas dari $\mathrm{JB}<0,05$ berarti residual model tidak terdistribusi normal (Athoillah, 2015).

\section{Uji Multikolinearitas}

Menurut Gujarati, bahwa gejala multikolinearitas dan signifikansi dari variabel yang dipergunakan dapat dilihat dari $\mathrm{R}^{2}$ nya. Jika $\mathrm{R}^{2}$ tinggi tetapi terdapat banyak variable yang tidak signifikan maka diduga terjadi multikolinearitas pada variablevariabel tersebut (Gujarati, 2013). Pada penelitian ini, hasil dari $\mathrm{R}^{2}$ sebesar 0.967311 atau $97 \%$ dan semua variable signifikan. Maka variable dalam model penelitian ini dapat diambil kesimpulan terbebas dari multikolinearitas.

\section{Uji Autokorelasi}

Untuk mendeteksi autokorelasi, (Athoillah : 2015) dapat dilakukan uji statistik melalui uji Durbin-Watson (DW test$)$. Dasar pengambilan keputusan ada tidaknya autokorelasi adalah sebagai berikut: 


\section{p-ISSN 2548-5032 e-ISSN 2714-769X}

\section{Doi : $\mathbf{1 0 . 3 7 0 5 8 / j e s . v 5 i 2 . 1 9 4 9}$}

1. Bila nilai DW terletak di antara batas atas atau upper bound (du) dan (4-du) maka koefisien autokorelasi $=0$, berarti tidak autokorelasi.

2. Bila nilai DW lebih rendah dari pada batas bawah atau lower bound $(d l)$ maka koefisien autokorelasi $>0$, berarti ada autokorelasi positif.

3. Bila DW lebih besar dari (4- $d l)$ maka koefisien autokorelasi $<0$, berarti ada autokorelasi negative.

Tabel 7

\section{Hasil Uji AutoKorelasi}

\begin{tabular}{|lllr}
\hline \hline R-squared & 0.641533 & Mean dependent var & 42904.15 \\
Adjusted R-squared & 0.628955 & S.D. dependent var & 156131.1 \\
S.E. of regression & 95104.81 & Sum squared resid & $5.16 \mathrm{E}+11$ \\
F-statistic & 51.00528 & Durbin-Watson stat & 1.590001 \\
Prob(F-statistic) & 0.000000 & & \\
\hline \hline
\end{tabular}

Dari hasil uji autokorelasi di atas tidak menunjukkan adanya autokorelasi karena $d$ di atas ada diantara $d_{l}$ dan $d_{u}$ pada tabel Durbin-Watson.

\section{Pengujian Kriteria Statistik}

Ringkasan hasil pengujian dapat terlihat pada tabel di bawah:

\begin{tabular}{|l|c|c|c|c|}
\hline \multicolumn{1}{|c|}{ Variabel } & Koefisien & t-statistik & Probability & Kesimpulan \\
\hline C & 90600.81 & 0.554534 & 0.5816 & Signifikan \\
\hline Pembiayaan Bank & 0.167449 & 3.379253 & 0.0014 & Signifikan \\
Syariah & & & & \\
\hline Tingkat Pendidikan & 11153.26 & 3.329593 & 0.0016 & Signifikan \\
\hline R-squared & 0.967311 & & & \\
F-statistik & 219.8206 & & & \\
Prob (F-statistik) & 0.000000 & & & \\
\hline
\end{tabular}

Sumber: hasil olah data eviews 7

\section{Koefisien Determinasi}

Berdasarkan hasil analisis regresi berganda pengaruh pembiayaan bank syariah, dan tingkat pendidikan terhadap pertumbuhan ekonomi pada enam provinsi di Pulau Jawa diperoleh nilai koefisien determinasi atau $\mathrm{R}^{2}$ sebesar 0.967311. Nilai ini 
Doi : $\mathbf{1 0 . 3 7 0 5 8 / j e s . v 5 i 2 . 1 9 4 9}$

menunjukkan bahwa variable-variabel independen telah memberikan kontribusi sebesar 96,73 persen dalam mempengaruhi variabel Y (pertumbuhan ekonomi) pada enam provinsi di Pulau Jawa. Sedangkan sisanya sebesar 3,27 persen dipengaruhi oleh variabel-variabel lain yang tidak diteliti.

\section{Uji t atau pengujian secara parsial}

Dari hasil analisis menunjukkan bahwa pembiayaan bank syariah dengan nilai t-hitung sebesar 3.379253 dengan probabilitas sebesar $0.0014(0.0014<0,05)$ maka Ho ditolak sehingga pembiayaan bank syaraiah berpengaruh signifikan terhadap pertumbuhan ekonomi. Nilai koefisien sebesar 0,168 menunjukkan bahwa variabel pembiayaan bank syaraiah memiliki arah hubungan positif dan signifikan terhadap pertumbuhan ekonomi.

Variabel tingkat pendidikan dengan nilai t-hitung sebesar 3.329593 dan probabilitas sebesar 0.0016 jika dibandingkan dengan $\alpha=5 \%$ yang ditetapkan $(0.0016<0,05)$ maka Ho ditolak sehingga variabel tingkat pendidikan berpengaruh signifikan terhadap pertumbuhan ekonomi. Nilai koefisien sebesar 11153.26 menunjukkan bahwa variabel tingkat pendidikan memiliki arah hubungan positif dan signifikan terhadap pertumbuhan ekonomi.

\section{Uji $F$ atau pengujian secara simultan}

Dari hasil analisis data menunjukkan bahwa F-hitung yang diperoleh adalah sebesar 219.8206 dengan probabilitas yang diperoleh lebih kecil dari $\alpha=5 \%$ yang ditetapkan $(0,000<0,05)$. Dengan demikian Ho ditolak, maka variabel pembiayaan bank syariah dan tingkat pendidikan secara bersama-sama (simultan) berpengaruh secara signifikan terhadap pertumbuhan ekonomi pada enam provinsi di Pulau Jawa.

\section{Pengaruh Pertumbuhan Ekonomi, Kesempatan Kerja, dan Kesejahteraan Masyarakat Terhadap Pertumbuhan Perbankan Syariah}

Persamaan model yang didapat dari estimasi pengaruh pembiayaan bank syariah dan tingkat pendidikan berpengaruh terhadap pertumbuhan ekonomi, adalah sebagai berikut: $\mathrm{Y}=0.167449(\mathrm{X} 1)+11153.26(\mathrm{X} 2)$. Persamaan tersebut dapat inter-prestasikan 


\section{Doi : $\mathbf{1 0 . 3 7 0 5 8 / j e s . v 5 i 2 . 1 9 4 9}$}

bahwa setiap kenaikan $0.167449(X 1)$ dan kenaikan 11153.26(X2), maka Y akan naik satu satuan. Atau dengan kata lain jika pembiayaan bank syariah naik sebesar 10 persen maka akan menyebabkan pertumbuhan ekonomi naik sebesar 1,67 satuan. Dan jika tingkat pendidikan naik sebesar 10 persen maka pertumbuhan ekonomi akan naik sebesar 111.530 satuan.

Dengan demikian hasil penelitian ini mendukung hasil penelitian yang dilakukan oleh Salahuddin El Ayubi, Lukytawati Anggraeni, Almira Dyah Mahiswary, yang berjudul, Pengaruh Bank Syariah terhadap Pertumbuhan Ekonomi Indonesia. Dimana hasil penelitiannya bahwa pembiayaan yang dilakukan perbankan syariah dapat mempengaruhi pertumbuhan ekonomi, juga sejalan dengan penelitian yang dilakukan oleh Ali Rama, dengan judul, Perbankan Syariah dan Pertumbuhan Ekonomi Indonesia dimana sector keuangan dapat mempengaruhi pertumbuhan ekonomi melalui kemampuannya memberikan pinjaman sehingg sekto riil dapat tumbuh. Sementara hasil penelitian pengaruh variable tingkat pendidikan berpengaruh terhadap pertumbuhan ekonomi mendukung hasil penelitian yang dilakukan oleh Nugroho SBM. Dengan judul penelitian, Pengaruh Pendidikan Terhadap Pertumbuhan Ekonomi. Data pendidikan dengan Angka Melek Huruf (AMH) sebagai ukurannya, dan pertumbuhan ekonomi dengan Produk Domestik Bruto (PDB) sebagai ukurannya. Menunjukkan hasil analisis uji asumsi klasik bahwa AMH berpengaruh secara signifikan terhadap PDB Indonesia. Hasil uji koefisien determinasi (R2) menunjukkan bahwa naik turunnya PDB Indonesia bisa dijelaskan oleh Angka Melek Huruf, dan dari setiap kenaikan 1 poin AMH akan menaikkan PDB Indonesia sebesar 0,962 milyar rupiah.

\section{KESIMPULAN}

1. Pembiayaan perbankan syariah berpengaruh signifikan terhadap pertumbuhan ekonomi pada enam provinsi di Pulau Jawa, selama kurun waktu penelitian tahun 2009 sampai dengan tahun 2018

2. Tingkat pendidikan berpengaruh signifikan terhadap pertumbuhan ekonomi pada enam provinsi di Pulau Jawa, selama kurun waktu penelitian tahun 2009 sampai dengan tahun 2018

3. Pembiayaan perbankan syariah dan tingkat pendidikan masyarakat pada enam provinsi di pulau Jawa secara serentak (simultan) berpengaruh signifikan terhadap 


\section{p-ISSN 2548-5032 e-ISSN 2714-769X}

\section{Doi : $10.37058 /$ jes.v5i2.1949}

pertumbuhan ekonomi selama kurun waktu penelitian tahun 2009 sampai dengan tahun 2018

\section{Saran}

1. Untuk meningkatkan pertumbuhan ekonomi pemerintah hendaknya memberikan ruang gerak dan perhatian yang lebih besar lagi kepada perbankan syariah, sehingga perbankan syariah lebih cepat dalam pertumbuhannya yang pada akhirnya perbankan syariah mampu melayani keperluan masyarakat dengan memberikan pembiayaan atau permodalan kepada masyarakat sehingga sektor riil masyarakat lebih tumbuh dan berkembang.

2. Pemerintah hendaknya lebih banyak mengalokasikan keuangannya pada sektor pendidikan sehingga tingkat pendidikan masyarakat meningkat. Karena terbukti tingkat pendidikan masyarakat dapat mempengaruhi kualitas sumber daya manusia (SDM), yang akhirnya dapat mempengaruhi pertumbuhan ekonomi.

3. Pembiayaan perbankan syariah dan tingkat pendidikan masyarakat terbukti berpengaruh secara signifikan terhadap pertumbuhan ekonomi. Namun dalam penelitian ini tidak dirinci mengenai pembiayaan yang disalurkan apakah pembiayaan untuk konsumtif ataukah untuk kredit usaha kecil dan menengah (UKM) yang dapat meningkatkan pertumbuhan ekonomi. Untuk itu sebaiknya ada penelitian lanjutan terkait pengaruh pembiayaan perbankan syariah terhadap pertumbuhan UKM dan dampaknya terhadap pertumbuhan ekonomi.

\section{REFERENSI}

Agustus, pertumbuhan kredit perbankan melambat. (n.d.). Retrieved October 30, 2019, from https://keuangan.kontan.co.id/news/agustus-pertumbuhan-kredit-perbankanmelambat-1

Antonio, M. S. (2001). Bank syariah: Dari teori ke praktik. Jakarta: Gema Insani.

APK-APM. (n.d.). Retrieved October 30, 2019, from http://apkapm.data.kemdikbud.go.id/

Arsyad, L. (2016). Ekonomi pembangunan. Yogyakarta: Bag. Penerb. Sekolah Tinggi Ilmu Ekonomi-YKPN. 
Doi : $10.37058 /$ jes.v5i2.1949

Ayub, M. (2013). Understanding Islamic Finance. Jakarta: Gramedia Pustaka Utama.

Baroroh, U. (2012). Analisis Sektor Keuangan Terhadap Pertumbuhan Ekonomi Regional di Wila- yah Jawa, Pendekatan Model Levine. Jurnal Etikomi, 11(2).

El Ayubi, S., Anggraeni, Lukytawati., \& Mahiswary, A. D. (2017). Pengaruh Bank Syariah terhadap Pertumbuhan Ekonomi Indonesia. Jurnal AlMuzara'ah, 5(2), 88-106.

Gujarati, D. N. (2013). Dasar-Dasar Ekonometrika. Erlangga.

Hastuti, R. K. (n.d.). Ketua LPS: Kondisi Perbankan Syariah Cukup Berat. Retrieved October 30, 2019, from Syariah website: https://www.cnbcindonesia.com/syariah/20190606191828-29-76983/ketua-lpskondisi-perbankan-syariah-cukup-berat

Inggrid. (2006). Sektor Keuangan dan Pertumbuhan Ekonomi di Indonesia: Pendekatan Kausalitas dalam Multivariate Vector Error Correction Model (VECM). 50 JURNAL MANAJEMEN DAN KEWIRAUSAHAAN, 8(1). Retrieved from http://www.petra.ac.id/ puslit/journals/dir.php?DepartmentID=MAN

Jaelani. (2015). Studi Efisiensi Bank Umum di Indonesia Tahun 2002-2013, (Komparasi Faktor-faktor Penjelas Efisiensi Antara Bank Umum Konvensional dengan Bank Umum Syariah). Program Studi Ilmu Manajemen, Sekolah Pasca Sarjana Universitas Pendidikan Indonesia, Bandung.

Jhingan, M. (2016). Ekonomi Pembangunan dan Perencanaan. Jakarta: RajaGrafindo Persada.

Latumaerissa, J. R. (2015). Perekonomian Indonesia dan dinamika ekonomi global. Jakarta.

Maski, G. (2010). Analisis Kausalitas antara Sektor Keuangan dan Pertumbuhan Ekonomi di Indonesia. Jurnal Ekonomi Dan Pembangunan Indonesia, 10(2), 143-158. https://doi.org/10.21002/jepi.v10i2.117

Nugroho. (2014). Pengaruh Pendidikan Terhadap Pertumbuhan Ekonomi. Media Ekonomi dan Manajemen, 29(2).

Olufemi Adeyeye, P. (2015). Does Supply- Leading Hypothesis hold in a Developing Economy? A Nigerian Focus. Procedia Economicsang Finance. Retrieved from https://core.ac.uk/download/pdf/82469979.pdf 
Doi : $10.37058 /$ jes.v5i2.1949

Pengangguran \& Tenaga Kerja di Indonesia | Indonesia Investments. (n.d.). Retrieved October 30, 2019, from https://www.indonesiainvestments.com/id/keuangan/angka-ekonomi-makro/pengangguran/item255?

Pertumbuhan Ekonomi Maluku dan Papua Diproyeksi Lampaui Jawa. (n.d.). Retrieved October 30 , 2019 , from https://www.cnnindonesia.com/ekonomi/20181127161912-532349628/pertumbuhan-ekonomi-maluku-dan-papua-diproyeksi-lampaui-jawa

Putra, Windhu. (2018). Perekonomian Indonesia, Penerapan Beberapa Teori Ekonomi Pembangunan di Indonesia. Depok: RajaGrafindo Persada.

Rahardja, P., \& Manurung, M. (2014). Teori Ekonomi Makro. Jakarta: Fakultas Ekonomi Universitas Indonesia.

Rama, A. (2013). Perbankan Syariah dan Pertumbuhan Ekonomi Indonesia. Jurnal Signifikan, 2(1).

Sekaran, U., \& Bougie, R. (2016). Research Methods For Business: A Skill Building Approach. John Wiley \& Sons.

Sukirno, S. (2006). Ekonomi pembangunan: Proses, masalah, dan dasar kebijakan. Kencana (Prenada Media).

Tenaga Kerja Asing Masuk RI Melesat 38\%, Terbanyak Asal China. (n.d.). Retrieved October 30, 2019, from https://finance.detik.com/berita-ekonomi-bisnis/d4699585/tenaga-kerja-asing-masuk-ri-melesat-38-terbanyak-asal-china

Tertinggi Sejak 2014, BPS: Ekonomi Indonesia 2018 Tumbuh 5,17 Persen. (n.d.). Retrieved October 30, 2019, from https://www.menpan.go.id/site/beritaterkini/berita-daerah/tertinggi-sejak-2014-bps-ekonomi-indonesia-2018-tumbuh-5-17persen

Todaro, M. P., \& Smith, S. C. (2006). Economic Development. Jakarta: Erlangga. 